\title{
Influence of Firm-Specific Determinants on the Profitability of Companies in Agri-Food Sector in Bosnia and Herzegovina: Research Project
}

\author{
Dalila Ivković \& Ermin Cero \\ International Burch University, Sarajevo, BOSNIA AND HERZEGOVINA \\ Faculty of Economics and Social Sciences
}

Received: 12 January 2021 - Accepted: 30 April 2021 • Published Online: 30 July 2021

\begin{abstract}
The main objective of the undertaken study is to examine the influence of firm-specific determinants on the profitability of companies in the agri-food sector (agricultural production and food processing) in Bosnia and Herzegovina (B\&H). For this purpose, we examine the impact of factors that are considered as determinants of firm profitability such as size, age, liquidity, leverage, and growth. The impact of the specific characteristics of the companies is tested on profitability measured by return on assets (ROA) in the agricultural and food processing sector in $\mathrm{B} \& \mathrm{H}$. The analysis is based on the collection of quantitative data published in the food financial annual reports of the listed agricultural and processing companies in B\&H over a period of five years (2015-2019). A research model with crucial variables with five independent variables (size, age, liquidity, leverage, and growth rate) and one dependent variable (profitability) was developed based on the literature review. The study outcomes will give an insight into the firmspecific factors that are important in examining the profitability of companies in the agri-food sector in B\&H. Furthermore, the results of this research will serve as a basis for further studies in which the number of variables observed will be extended. Moreover, the results are expected to be useful for the management of the company to direct business decisions towards improving the company's profitability.
\end{abstract}

Keywords: firm-specific determinants, profitability, agri-food sector, agricultural and food processing companies, Bosnia and Herzegovina.

\section{Introduction}

Agriculture and food processing is an important sector of the economy of Bosnia and Herzegovina. According to official statistical data for 2019 (Plecher, 2020), agriculture contributed around 6.1\% to the overall Gross Domestic Product (GDP) of Bosnia and Herzegovina. Although post-war conditions and a complex socio-economic structure negatively affected the development of the sector as a whole, according to data from World Bank (2020), the agri-food sector employs around 15\% of all employees in Bosnia and Herzegovina. Therefore, because of its significant economic and social importance, the agri-food sector in Bosnia and Herzegovina deserves the examination of the factors impacting its profitability.

Businesses are always significant as well as their determinants. Each nation is trying to build a desirable business operating climate. In a dynamic economy, company owners must

(C) Authors. Terms and conditions of Creative Commons Attribution 4.0 International (CC BY 4.0) apply. Correspondence: Cero Ermin, International Burch University, Faculty of Economics and Social Science, Sarajevo, BOSNIA AND HERZEGOVINA. E-mail: ermin.cero@ibu.edu.ba. 
D. Ivković \& E. Cero - Influence of Firm-Specific Determinants on the Profitability of...

learn how to reach a satisfactory level of profitability. The ratio for measuring the company's efficiency is profitability. It is a crucial feature of financial statements for a company. A business's profitability reflects the potential of a company to produce profits at a rate of sales, assets, and capital stock cost over a certain period of time (Gitman, Zutter, Elali \& Roubaie, 2013). For a variety of interest groups, beginning with the shareholders, future investors, and state and supervisory authorities, the business of a corporation is of considerable significance. Understanding the determinants of profitability is a crucial element that allows managers to establish a successful profitability strategy for their business. Also, Goddard, Tavakoli \& Wilson (2006) stated that the identification of firm-specific determinants that impact profitability is an important research field in economics, strategic management, and accounting and finance.

This research examines the impact of firm-specific determinants on profitability for a sample of the B\&H agricultural and food processing companies. It assesses the main determinants of firm profitability in the period from 2015 to 2019. The main research objectives of the study are the folowing: companies.

- To examine the impact of firm-specific determinants on the profitability of the

- To explore the relationship between size and profitability of the B\&H agricultural and food processing companies.

- To investigate the relationship between age and profitability of the $\mathrm{B} \& \mathrm{H}$ agricultural and food processing companies.

- To investigate the relationship between the two objectives of liquidity and profitability of the B\&H agricultural and food processing companies.

- To find out the relationship between leverage and profitability of the B\&H agricultural and food processing companies.

- To find out the relationship between growth and profitability of the B\&H agricultural and food processing companies.

- To draw a conclusion on the relationship of firm-specific determinants and profitability of the B\&H agricultural and food processing companies.

Statistical Package for the Social Sciences SPSS 20.0 will be used to conduct quantitative analysis (descriptive statistics, multiple linear regression, correlation matrix, multicollinearity and VIF test - Variable Inflation Factors) using secondary data based on financial annual reports of the listed agricultural and food processing companies in Bosnia and Herzegovina. In addition, the research will use additional descriptive statistics and correlation matrix to analyze the data collected. The analysis will be conducted for a period of five years (20152019).

The following sections of this paper are structured as follows: Section 2 reviews the literature on specific determinants of the firm and its effect on profitability; Section 3 contains the research hypotheses and model that explains the core of this research; Section 4 explains data collection and methods that are used for a statistical analysis in order to reach results and draw a conclusion in Section 5 . 


\section{Literature review}

\subsection{Definitions and concept evolution}

Many scientists and experts have conducted their studies on the factors that determine the profitability and success of companies. The determinants of profitability have been analyzed from different perspectives and in different years. These research studies explored external determinants, as well as internal determinants and the specific characteristics of companies in various industries. According to Yazdanfar (2013), company sustainability is one of the primary prerequisites for long-term business stability and performance. The accomplishment and other financial results of the company are greatly impacted by the determinant of the business's profitability. These variables are significant because they have an impact on economic development, wages, development, and technological change. The company's primary aim is to improve its profitability. Since 1990, many scientists and researchers have focused on examining the profitability of a corporation. According to various theoretical studies, profitability is one of the most important tools in a company's operating system. A significant number of scientists offer their own definition of profitability. Profitability is the ratio of the overall effectiveness of management based on the returns generated from sales and investment. According to Harward and Upto (1961), profitability is the ability of a given investment to earn a return from its use. In the same sense conveyed by Husan (2001), profitability is the company's ability to benefit from the assets, sales and capital.

For the purpose of this study, we focused mainly on the period from 2015 to 2020. The following ones are relevant and helpful for this study.

\subsection{Studies on profitability and its determinants}

Through applying the multilevel method of Hierarchical Linear Modeling (HLM), Zouaghi, Garcia and Hirsch (2017) examined the effect of firm-specific, industry-specific, regionspecific, and year-specific influences on firm profitability. Using a sample of 3,273 Spanish agrifood companies during the period 2006-2013, these researchers concluded that firm-specific factors have a stronger impact on firm profitability than industry and region determinants. Margaretha and Supartika (2016) used a sample of SMEs firm listed on the Indonesia Stock Exchange to analyze the influence of firm-specific determinants on profitability. They stated that the size of the company, growth, and lagged profitability, have a negative impact on profitability. Productivity and industry affiliation variables, however, have a positive effect on profitability. An additional study investigating the relationship between firm-specific factors and profitability. AlJafari and Al Samman (2015) used a sample of 17 industrial companies in Oman for the 20062013 period. The results obtained from regression analysis showed that size, growth, and working capital affect profitability positively and significantly. The results also indicated a negative and significant relationship between profitability and financial leverage.

In another study, focusing on the Croatian food and beverage industry, Pervan and Mlikota (2013) reported what determines the profitability over the years 1999-2009. Their empirical results showed that lagged profitability, size, and concentration ratio affect profitability positively and significantly, while the company's debt ratio affects profitability negatively and significantly. Lazar (2016) researched the determinants of firm performance for Romanian nonfinancial companies over twelve years period (2000-2011). As concluded by this researcher, firmspecific factors such as tangibles, size, leverage, and the intensity of labor affect profitability negatively. Also, they stated that sales growth and value-added have a positive effect on profitability. Factors that influence the profitability of 153 real sector firms in Turkey in the period between 2005 and 2012 are investigated by Işık (2017). Panel data review findings showed that all business-specific factors, including company size, company age, liquidity ratio, the tangibility of 
D. Ivković \& E. Cero - Influence of Firm-Specific Determinants on the Profitability of...

assets, debt, and financial crisis, have an impact on the overall profitability of companies in the real sector. Results also indicated that growth opportunities have no impact on the profitability of the listed companies. In another study, analyzing the factors that impact the profitability of 120 manufacturing companies in Istanbul, Isak and Tasgin (2017) concluded that determinants such as past profitability, net working capital, size and economic growth affect profitability positively and significantly. They also found that financial risk and R\&D cost have a negative effect on the profitability.

Contrary, the study conducted by Mijić, Zekić and Jakšić (2016) using a sample of 12 meat processing industries in Serbia for the period 2011-2015 resulted in a significant positive relationship between the profitability of the company and the growth variable. The results also showed that the high debt ratio has a negative impact on the company's profitability. In another study, where the key objective of the research was the analysis of firm-specific determinants using a sample of 2,366 hotels in Italy over nine-year period, Menicucci (2018) discovered that the financial recession, the corporate model, and the management structure impact the profitability of hotel companies. The results showed that size, internationalization, place, accommodation, and chain affiliation have a positive effect on profitability. Wasiuzzaman (2015) analyzed the relationship between the management of working capital and profitability of the company in a sample of 192 Malaysian companies for the period from 1999 to 2008. The study found that enhancing the productivity of working capital by reducing investment in working capital results in higher firm value.

Considering the latest research studies conducted on this topic, one study revealed that size and growth have a positive effect on profitability. However, they additionally stated that tangible assets, business risk, and debt have a negative relationship with profitability (Gharaibeh \& Bani Khaled, 2020). Vieira, Neves and Dias (2019) observed that the determinants of firm success differ according to the component used to assess performance. This research was focused on a sample of 37 non-financial companies for a period of six years (2010-2015). In particular, this finding indicates that the company-specific factors are not so relevant to clarify performance when the researchers use a business measure of performance. They concluded that the macroeconomic variables clarify the firm's performance more efficiently. Besides, many researchers have stated in their results the significant impact of firm-specific determinants on the profitability of companies (Abbas, Bashir, Manzoor \& Akram, 2013; Nunes \& Serrasqueiro, 2015; Akben-Selcuk, 2016; Nanda \& Panda, 2018; Egbunike \& Okerekeoti, 2018; Cyril \& Singla, 2020).

Studies of profitability and its determinants are not deeply discovered and almost nonexistent for the B\&H agricultural and food processing companies. There are only a few research papers connected with this topic. The review of previous research shows that the profitability of a company is determined by a range of indicators. In summarizing some of the previous studies, in most cases, attention is paid to variables such as company size, liquidity, leverage, age, industrial affiliation, leverage, growth, working capital, tangible assets, etc. For the purpose of this research study, the variables such as firm size, firm age, liquidity, leverage and growth will be used to evaluate the relationship with the profitability.

\section{Hypotheses and research model}

The main problem being investigated in this study is comprised of the impact of firmspecific determinants, namely size, age, liquidity, leverage and growth, on the profitability of the agricultural and food processing companies in Bosnia and Herzegovina.

H1: There is a statistically significant relationship between firm size and profitability of companies in the agricultural and food processing sector in Bosnia and Herzegovina. 
H2: There is a statistically significant relationship between firm age and profitability of companies in the agricultural and food processing sector in Bosnia and Herzegovina.

H3: There is a statistically significant relationship between liquidity and profitability of companies in the agricultural and food processing sector in Bosnia and Herzegovina.

$\mathrm{H} 4$ : There is a statistically significant relationship between leverage and profitability of companies in the agricultural and food processing sector in Bosnia and Herzegovina.

$\mathrm{H}_{5}$ : There is a statistically significant relationship between growth and profitability of companies in the agricultural and food processing sector in Bosnia and Herzegovina.

below.

We have presented our research model based on the literature review in the figure

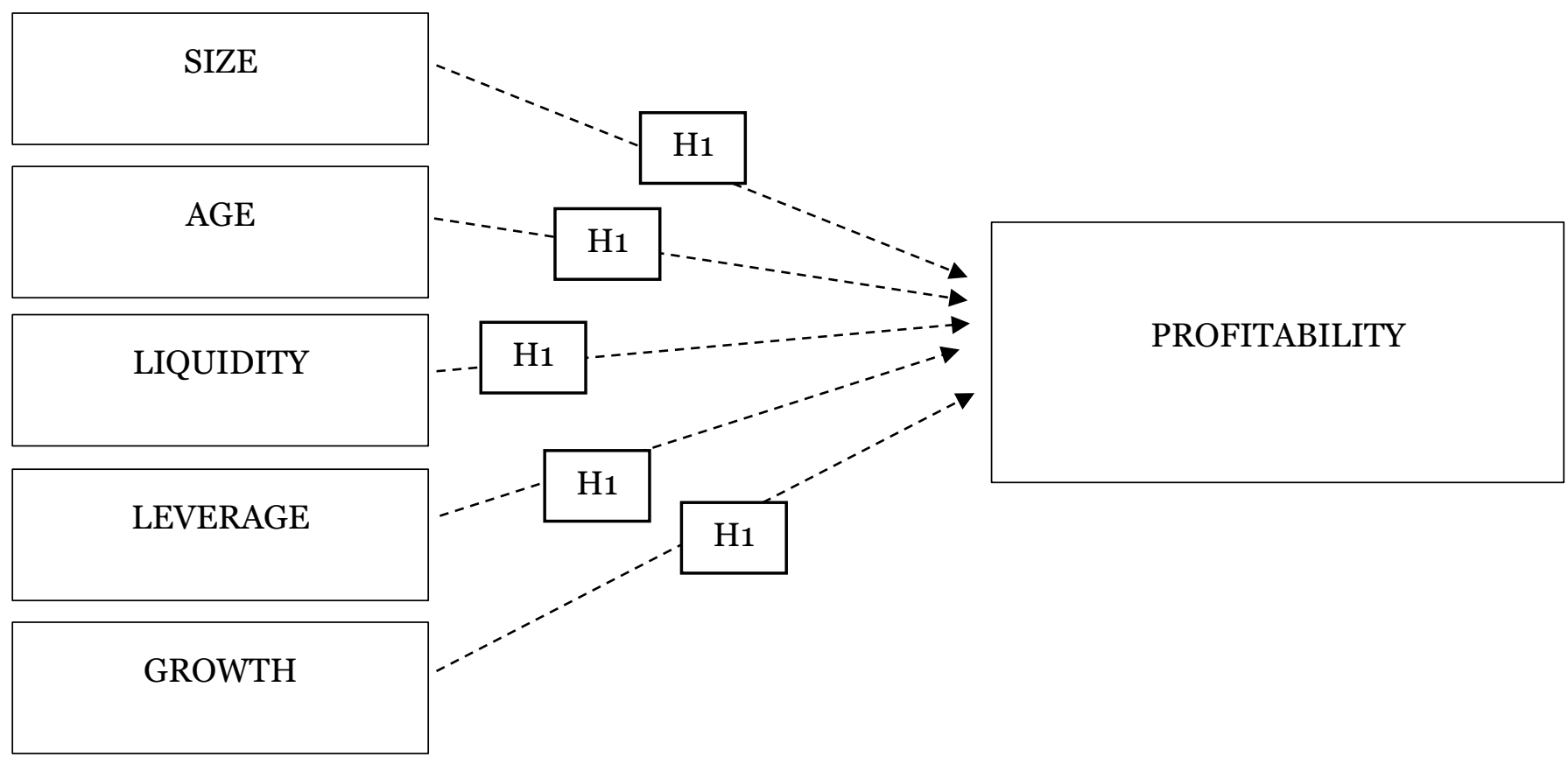

Figure 1. Proposed research model

\section{Methodology}

This part of the research proposal will explain the data collection activities, variables included in the study and the research methods that will be used in this study to examine the relationship between firm-specific determinants and profitability.

\subsection{Data}

The data that will be used in this study refers to a sample of the B\&H agricultural and food processing companies. Data was collected through business intelligence database containing official financial reports of all companies in Bosnia and Herzegovina. In addition, the period that will be covered by this analysis includes financial reports for the five-year period (2015-2019) of the listed companies in agricultural and food processing sector. 
D. Ivković \& E. Cero - Influence of Firm-Specific Determinants on the Profitability of...

\subsection{Variables and measurement}

In order to explore how the company's profitability reacts to company-specific determinants, we developed a profitability model in which we used different variables (one dependent and five independent variables) selected on the basis of relevant theory and literature. This research study includes variables that affect the profitability of agricultural and food processing companies in Bosnia and Herzegovina. According to Asiri (2015), return on assets (ROA) is the most relevant factor in explaining the market value of companies. As a result, profitability as a dependent variable is expressed by Return on assets. The five independent variables are measured as follows: (1) firm size, natural logarithm of the firm's total assets; (2) firm age, natural logarithm of the number of years since the firm's incorporation; (3) liquidity, current assets / current liabilities; (4) leverage, total debt / total assets, and; (5) growth, sales growth rate. Moreover, a summary of the variables and their measurements is provided in the table below.

Table 1. Definition of variables and their measurement

\begin{tabular}{|l|l|l|}
\hline Dependent Variable (X) & Scale \\
\hline Variables & Measurements & Ratio \\
\hline Profitability & ROA Net Income / Total Assets \\
\hline Independent Variable (Y) & Ratio \\
\hline Firm Size & Logarithm of Total Assets & Ratio \\
\hline Firm Age & Logarithm of Year & Ratio \\
\hline Liquidity & (Current Assets / Current Liabilities) & Ratio \\
\hline Leverage & (Total Debt / Total Assets) & Ratio \\
\hline Growth & Sale growth rate & \\
\hline
\end{tabular}

\subsection{Research techniques}

Different scientific methods will be used in this research study. For the purpose of this research, SPSS Statistics software 20.0 will be used to analyze data and provide the results in numerical percentages. The research will use descriptive statistics and correlation matrix to analyze the data collected and quantitative analysis (linear regression, correlation, regression analysis and diagnostics test (multicollinearity test with the method VIF - Variable Inflation Factors).

\section{Conclusion}

Although profitability in the manufacturing industry as a whole has been widely examined, studies relating to the particular industries within this industry are rare. This is especially the case with the agricultural and food processing sector in Bosnia and Herzegovina. Keeping in mind that one of the key objectives of each business is profitability, it is understandable why the profitability determinants of the firms have drawn the attention of many researchers. The key objective of this research analysis was to investigate the impact of firm-specific determinants on the profitability of companies in the agri-food sector (agricultural production and food processing) in Bosnia and Herzegovina. The agriculture and food processing industry is an important field of economic growth in Bosnia and Herzegovina. This industry is significant in terms of production facilities, the income it generates and the number of employees in the agrifood sector.

From this research study, many contributions are expected. Firstly, recognition of key determinants that have an impact on the profitability of agricultural and food processing 
companies in Bosnia and Herzegovina. Development of a research model and analysis of the impact of firm-specific factors on the profitability of companies in the agri-food sector. An overview of the results and providing a clear picture of the profitability of the listed companies. Furthermore, the results of this research will help managers to increase the profitability of listed companies. In addition, the results obtained will serve investors to make clear business decisions.

Besides, the impact of the COVID-19 pandemic on firm profitability should be researched. Moreover, this research can serve as a basis for future studies where a wider set of variables will be covered.

\section{Acknowledgements}

This research did not receive any specific grant from funding agencies in the public commercial, or not-for-profit sectors.

The authors declare no competing interests.

\section{References}

Abbas, A., Bashir, Z., Manzoor, S., \& Akram, M. N. (2013). Determinants of firm's financial performance: An empirical study on textile sector of Pakistan. Business and Economic Research, 3(2), 7686. https://doi.org/10.5296/ber.v3i2.3958

Akben-Selcuk, E. (2016). Factors affecting firm competitiveness: Evidence from an emerging market. International Journal of Financial Studies, $4(2), \quad$ 1-10. https://doi.org/https://doi.org/10.3390/ijfs4020009

Al-Jafari, M. K., \& Al Samman, H. (2015). Determinants of profitability: Evidence from industrial companies listed on Muscat Securities market. Review of European Studies, 7(11), 303. https://doi.org/10.5539/res.v7n11p303

Asiri, B. K. (2015). How investors perceive financial ratios at different growth opportunities and financial leverages. Journal of Business Studies Quarterly, 6(3), 1-12.

Cyril, E. J., \& Singla, H. K. (2020). Comparative analysis of profitability of real estate, industrial construction and infrastructure firms: evidence from India. Journal of Financial Management of Property and Construction, 25(2), 273-291.

Egbunike, C. F., \& Okerekeoti, C. U. (2018). Macroeconomic factors, firm characteristics and financial performance: A study of selected quoted manufacturing firms in Nigeria. Asian Journal of Accounting Research, 3(2), 142-168. https://doi.org/10.1108/AJAR-09-2018-0029

Gharaibeh, O. K., \& Bani Khaled, M. H. (2020). Determinants of profitability in Jordanian services companies. Investment Management and Financial Innovations, 17(1), 277-290. https://doi.org/10.21511/imfi.17(1).2020.24

Gitman, L. J., Zutter, C. J., Elali, W., \& Roubaie, A. A. (2013). Principles of managerial finance (13 ${ }^{\text {th }}$ ed.). USA: Addison Wesle: Pearson Education, Ltd.

Goddard, J., Tavakoli, M., \& Wilson, J. O. (2006). Determinants of profitability in European manufacturing and services: evidence from a dynamic panel model. Applied Financial Economics, 15(18), 1269-1282. https://doi.org/10.1080/09603100500387139

Harward, M., \& Upto, K. (1961). Introduction to business finance. New York: Mc Graw Hill. 
D. Ivković \& E. Cero - Influence of Firm-Specific Determinants on the Profitability of...

Husnan, S. (2001). Fundamentals of securities portfolio theory and analysis. Yogyakarta: Publishers and Printing Unit AMP YKPN.

Isak, O., \& Tasgin, U. F. (2017). Profitability and its determinants in Turkish manufacturing industry: Evidence from dynamic panel data. International Journal of Economics and Finance, 9(8).

Işık, Ö. (2017). Determinants of profitability: Evidence from real sector firms listed in Borsa Istanbul. Business and Economics Research Journal, 8(4), 689-698. https://doi.org/10.20409/berj.2017.76

Lazar, S. (2016). Determinants of firm performance: Evidence from Romanian listed companies. Review of Economic and Business Studies, 9(1), 53-69. https://doi.org/10.1515/rebs-2016-0025

Margaretha, F., \& Supartika, N. (2016). Factors affecting profitability of small medium enterprises (SMEs) firm listed in Indonesia Stock Exchange. Journal of Economics, Business and Management, 4(2), 132-136.

Menicucci, E. (2018). The influence of firm characteristics on profitability: Evidence from Italian hospitality industry. International Journal of Contemporary Hospitality Management, 30(8), 28452868.

Mijić, K., Zekić, S., \& Jakšić, D. (2016). Profitability analysis of meat industry in Serbia. Facta Universitatis - Economics and Organization, 13(4), 379-386. https://doi.org/10.22190/FUEO1604379M

Nanda, S., \& Panda, A. K. (2018). The determinants of corporate profitability: an investigation of Indian manufacturing firms. International Journal of Emerging Markets, 13(1), 66-86. https://doi.org/10.1108/IJoEM-01-2017-0013

Nunes, P. M., \& Serrasqueiro, Z. (2015). Profitability determinants of Portuguese knowledge-intensive business services: empirical evidence using panel data models. Applied Economics Letters, 22(1), 51-56.

Pervan, M., \& Mlikota, M. (2013). What determines the profitability of companies: Case of croatian food and beverage industry. Economic Research - Ekonomska Istraživanja, 26(1), 277-286.

Plecher, H. (2020). Distribution of GDP across economic sectors in Bosnia and Herzegovina - 2019.

Vieira, E. S., Neves, M. E., \& Dias, A. G. (2019). Determinants of Portuguese firms' financial performance: panel data evidence. International Journal of Productivity and Performance Management, 68(7), 1323-1342. https://doi.org/10.1108/IJPPM-06-2018-0210

Wasiuzzaman, S. (2015). Working capital and firm value in an emerging market. International Journal of Managerial Finance, 11(1), 60-79.

World Bank (2020, June 21). Employment in agriculture (\% of total employment). Retrieved from The World Bank Data: https://data.worldbank.org/indicator/SL.AGR.EMPL.ZS?locations=BA.

Yazdanfar, D. (2013). Profitability determinants among micro firms: Evidence from Swedish data. International Journal of Managerial Finance, 9(2), 151-160.

Zouaghi, F., Garcia, M. S., \& Hirsch, S. (2017). What drives firm profitability? A multilevel approach to the Spanish agri-food sector. Spanish Journal of Agricultural Research, 15(3), 1-15. https://doi.org/10.5424/sjar/2017153-10713 